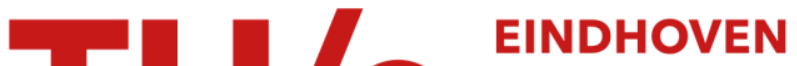 UNIVERSITY OF TECHNOLOGY
}

\section{Effect of glycounits on the antimicrobial properties and toxicity behavior of polymers based on quaternized DMAEMA}

\section{Citation for published version (APA):}

Alvarez-Paino, M., Munoz Bonilla, S., López-Fabal, F., Heuts, J. P. A., \& Fernández-García, M. (2015). Effect of glycounits on the antimicrobial properties and toxicity behavior of polymers based on quaternized DMAEMA. Biomacromolecules, 16(1), 295-303. https://doi.org/10.1021/bm5014876

DOI:

10.1021/bm5014876

Document status and date:

Published: 01/01/2015

\section{Document Version:}

Publisher's PDF, also known as Version of Record (includes final page, issue and volume numbers)

\section{Please check the document version of this publication:}

- A submitted manuscript is the version of the article upon submission and before peer-review. There can be important differences between the submitted version and the official published version of record. People interested in the research are advised to contact the author for the final version of the publication, or visit the $\mathrm{DOI}$ to the publisher's website.

- The final author version and the galley proof are versions of the publication after peer review.

- The final published version features the final layout of the paper including the volume, issue and page numbers.

Link to publication

\section{General rights}

Copyright and moral rights for the publications made accessible in the public portal are retained by the authors and/or other copyright owners and it is a condition of accessing publications that users recognise and abide by the legal requirements associated with these rights.

- Users may download and print one copy of any publication from the public portal for the purpose of private study or research.

- You may not further distribute the material or use it for any profit-making activity or commercial gain

- You may freely distribute the URL identifying the publication in the public portal.

If the publication is distributed under the terms of Article 25fa of the Dutch Copyright Act, indicated by the "Taverne" license above, please follow below link for the End User Agreement:

www.tue.nl/taverne

Take down policy

If you believe that this document breaches copyright please contact us at:

openaccess@tue.nl

providing details and we will investigate your claim. 


\title{
Effect of glycounits on the antimicrobial properties and toxicity behavior of polymers based on quaternized DMAEMA
}

\author{
Marta Álvarez-Paino, ${ }^{\dagger, \ddagger}$ Alexandra Muñoz-Bonilla, ${ }^{\dagger, \S}$ Fátima López-Fabal, " José L. Gómez-Garcés, " \\ Johan P.A. Heuts, ${ }^{\ddagger}$ and Marta Fernández-García* ${ }^{* \dagger}$ \\ ${ }^{\dagger}$ Instituto de Ciencia y Tecnología de Polímeros (ICTP-CSIC), Juan de la Cierva 3, 28006 Madrid, Spain \\ ${ }^{*}$ Department of Chemical Engineering and Chemistry, Eindhoven University of Technology, P.O. Box 513, 5600 MB Eindhoven, The \\ Netherlands \\ ${ }^{\S}$ Departamento de Química Física Aplicada, Facultad de Ciencias, Universidad Autónoma de Madrid, FranciscoTomás y Valiente 7, \\ Cantoblanco, 28049 Madrid, Spain \\ "Hospital Universitario de Móstoles, Río Júcar, s/n, 28935 Móstoles, Madrid, Spain
}

\section{Supporting Information}

ABSTRACT: Polymers with quaternary ammonium groups such as quaternized poly(2-(dimethylamino)ethyl methacrylate) (PDMAEMAQ) have been used as antimicrobial agents because of their demonstrated good antimicrobial activities against a huge number and types of microbes, although their cytotoxicity is also well-known. In this work block copolymers based on PDMAEMAQ were synthesized containing hydrophobic segments of poly(butyl methacrylate) to improve the antimicrobial activity and glycomonomer units with the aim of decreasing the cytotoxicity of the polymers. Hydrophobic butyl methacrylate (BMA) blocks were chain extended by statistical and block copolymers of DMAEMA and 2-\{[(D-glucosamin-2- $N$-yl $)$ carbonylethyl methacrylate (HEMAGl) glycomonomer of different compositions. In order to find the balance between antimicrobial activity and cytotoxicity, the selectivity index of each polymer was obtained from minimum inhibitory concentrations (MIC) and white and red blood cells toxicity measurements.

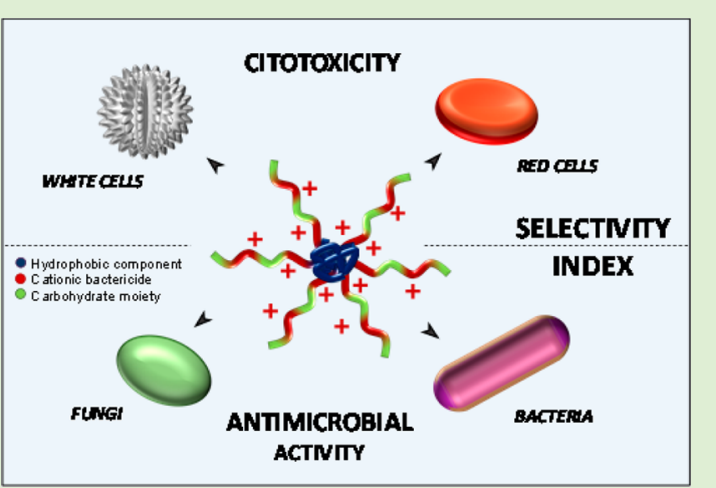

\section{INTRODUCTION}

Microbes form an integral part of our daily lives. Whereas many of these are present in our bodies and are actually beneficial, such as the intestinal bacteria Escherichia coli, or form part of natural processes, as in bread fermentation by Saccharomyces cerevisiae yeast, many global health problems are caused by microbial infections. Unfortunately, not all of these infections can be easily controlled by common antibiotics, and under certain conditions or high pathogenicity of microorganisms, infections can become uncontrolled. In fact, according to a report of the World Health Organization, ${ }^{1}$ around 17 million of worldwide deaths annually are caused by infectious diseases (mainly by bacteria). Although new antibiotics are continuously being discovered, infections still remain in the top of rankings of mortality from disease. The use of broad-spectrum antibiotics, abuses in their consumption, open the way for antimicrobial resistance. Nowadays, common hospital and community bacteria already present resistance against first, second, and even third lines of antibiotics, rendering current treatments almost ineffective. For instance, Klebsiella pneumonie have become resistant against cephalosporins and carbapenems, Escherichia coli against cephalosporins and fluoroquinolones, and Staphylococcus aureus adapts rapidly to acquire resistance against penicillin, methicillin, tetracycline, and erythromycin. ${ }^{2}$

It is clear from the above that there is an ongoing need in developing new antimicrobial agents. In this sense, antimicrobial polymers offer a high versatility for avoiding microbial contaminations or infections. Surface coatings, food packaging, biomedical devices, or water purification systems are some of the ways in which antimicrobial polymers can be incorporated, providing antimicrobial properties to the material. ${ }^{3-6}$ Possible design parameters for the polymers include the functional active groups, comonomer composition, molecular weight, ${ }^{7}$ the hydrophobic/hydrophilic balance, ${ }^{8}$ and the polymer architecture, ${ }^{9}$ all of which are known to affect the antimicrobial activity. ${ }^{4}$

In terms of functional antimicrobial groups, phosphonium or sulfonium salts, phenol and benzoic acid derivatives, or fluorine-containing molecules, among others, ${ }^{5,6}$ can be found. However, structures carrying quaternary ammonium groups are most widely reported. ${ }^{10,11}$ Polymers containing quaternized 2-

Received: October 7, 2014

Revised: November 28, 2014

Published: December 1, 2014 
(dimethylamino)ethyl methacrylate (DMAEMAQ) units are among those most widely studied due to their demonstrated good antimicrobial activity, ${ }^{12}$ despite their demonstrated cytotoxicity. In addition, unquaternized poly(2(dimethylamino)ethyl methacrylate) (PDMAEMA) displays high transfection efficiencies and $\mathrm{pH}$ response around $40{ }^{\circ} \mathrm{C}$; thus, it is useful not only for antimicrobial purposes, but also for gene transfection ${ }^{13}$ or drug delivery. ${ }^{14}$

As is well-known, bacterial membranes are negatively charged due to the high content in phosphatidylethanolamine on the outside. ${ }^{15}$ Then cationic biocides are able to adsorb onto the bacterial cell surface through electrostatic interactions, increasing accessibility into the cell. Once the polymer is attached on the bacteria, it should pass through the cell wall and cross the hydrophobic cytoplasmic membrane. Many studies changing the hydrophobic nature of the polymer have demonstrated that a certain amount of hydrophobic content improves its antimicrobial activity. ${ }^{16}$ Kuroda et al. ${ }^{17}$ studied the antimicrobial behavior of random amphiphilic copolymers based on DMAEMA and hydrophobic methacrylate monomers with side chains from methyl to hexyl and found that mole fractions of the hydrophobic component up to 0.4 decreases the minimum inhibitory concentrations (MICs) at least 10-fold, irrespective of the hydrophobic chain type. The type of hydrophobic chain, however, does play an important role in determining the cytotoxicity of the polymer. The longer the hydrophobic chain, the lower the hemolytic concentration $\left(\mathrm{HC}_{50}\right)$, and similar results have been described in the work of Dutta et al. ${ }^{18}$ for octyl and dodecyl alkyl moieties.

In summary, a good balance between antimicrobial activity and cytotoxicity should be found and, in this sense, many attempts have been carried out to decrease toxicity while maintaining antimicrobial activity. For instance, Locock et al. ${ }^{19}$ used guanidine moieties instead of amines as cationic biocidal group to obtain low hemotoxicity. In this work we incorporate carbohydrates into the copolymers based on DMAEMA with the expectation that the toxicity of these antimicrobial polymers will decrease due to the high biocompatibility of carbohydrate units. Some sugars are specifically recognized by membraneproteins in many human and bacterial membranes acting as sequestering agents. Also, glycopolymers have been previously synthesized as nontoxic vehicles in delivery systems. ${ }^{20}$ With the aim of finding this balance between antimicrobial activity and cytotoxicity, and taking into account the considerations as above, a library of polymers was prepared containing these three main components in different compositions and sequences (statistical and block): the antimicrobial agent (DMAEMAQ), the hydrophobic compound (butyl methacrylate, BMA), and the glycomonomer (HEMAGl). In order to address common current problems, the antimicrobial activity was assessed against common pathogenic bacteria and fungi, such as Pseudomonas aeruginosa, Staphylococcus aureus, or Candida parapsilosis by the microbroth dilution method, ${ }^{21}$ which is a well-established method for routine studies in microbiology departments in hospitals. Additionally, the cytotoxicity and selectivity of these polymers were determined to evaluate potential compositions that may be used in medical treatments against bacteria and fungi.

\section{EXPERIMENTAL SECTION}

Materials. $n$-Butyl methacrylate (BMA, 99\%, Sigma-Aldrich) was passed through a basic alumina column in order to remove inhibitor, and 2-hydroxyethyl methacrylate (HEMA, 99\%, Fluka) and
$N, N, N^{\prime}, N^{\prime \prime}, N^{\prime \prime}$-pentamethyldiethylenetriamine (PMDETA, 99\%, Sigma-Aldrich) were distilled prior to use. The reagents D-(+)-glucosamine hydrochloride (Fluka, 99\%), $p$-nitrophenyl chloroformate (Fluka, 97\%), ethyl 2-bromoisobutyrate (EBrIB, 98\%), copper(I) bromide ( $\mathrm{CuBr}$, 99.999\%), copper(I) chloride ( $\mathrm{CuCl}$, 99.995\%), 2(dimethylamino)ethyl methacrylate (DMAEMA, 98\%) and lithium bromide salt $(\mathrm{LiBr},>99 \%)$ were purchased from Sigma-Aldrich, and the quaternizing agent iodomethane $(\mathrm{MeI},>99 \%)$ was obtained from Riedel-de-Haën, all of them used as received. Regenerated cellulose dialysis tubing (CelluSep T1, $M_{\text {WCO }} 3500-5000 \mathrm{Da}$ ) was purchased from Membrane Filtration Products, Inc. The AR grade solvents, triethylamine (TEA, Scharlau, 99.8\%), tetrahydrofuran (THF, Scharlau, 99.8\%), toluene (Merck), chloroform (Merck), $N, N$ dimethylformamide (DMF, Scharlau), and dimethyl sulfoxide (DMSO, Scharlau), were utilized without further purification.

For microbiological and hemolytic studies, sodium chloride solution $(\mathrm{NaCl} 0.9 \%$, BioXtra, suitable for cell culture), phosphate buffered saline powder (PBS, pH 7.4), and Triton X-114 solution (BioUltra, for molecular biology, $\sim 10 \%$ in $\mathrm{H}_{2} \mathrm{O}$ ) were purchased from Aldrich and were used as received. Sheep blood (5\%) Columbia agar plates were purchased from bioMérieux and cation adjusted BBL Mueller Hinton broth used as microbial growth media was purchased from Becton, Dickinson and Company. For cytotoxicity assays, Trypan Blue solution used for cell staining (0.4\%, Sigma-Aldrich), sterile RPMI1640 culture medium with $20 \mathrm{mM}$ HEPES and L-glutamine (SigmaAldrich), and the cell viability reagent AlamarBlue (AbD Serotec) were used as received. American Type Culture Collection (ATCC): Pseudomonas aeruginosa (P. aeruginosa, ATCC 27853), Escherichia coli (E. coli, ATCC 25922), Staphylococcus aureus (S. aureus, ATCC 29213), and a staphylococcus coagulase-negative Staphylococcus epidermidis (S. epidermidis, ATCC 12221), were used as bacterial strains, and the yeast Candida parapsilosis (C. parapsilosis, ATCC 22109) was used as fungal strain and purchased from Oxoid. Human blood was taken from healthy donors (Hospital Universitario de Móstoles, Madrid, Spain).

Measurements. Copolymer compositions were determined using ${ }^{1} \mathrm{H}$ NMR spectroscopy. NMR spectra of PBMA macroinitiators and PBMA-b-PDMAEMA copolymer samples in $\mathrm{CDCl}_{3}(10 \mathrm{mg} / \mathrm{mL})$ were recorded on Bruker AV $300 \mathrm{MHz}$ spectrometer at $25^{\circ} \mathrm{C}$. Copolymers containing glycomonomer were analyzed with a Varian Inova 400 $\mathrm{MHz}$ spectrometer at $70{ }^{\circ} \mathrm{C}$ in DMF- $d_{7}(10 \mathrm{mg} / \mathrm{mL})$. The numberaverage molecular weights $\left(M_{n}\right)$ and polydispersity indexes $\left(M_{w} / M_{n}\right)$ of PBMA macroinitiators were measured by size exclusion chromatography (SEC) which was carried out on a Waters system (Waters Division Millipore) equipped with a Waters model 410 refractive-index detector and tetrahydrofuran as eluent at a flow rate of $1 \mathrm{~mL} / \mathrm{min}$. Separation module operating at $35^{\circ} \mathrm{C}$ was composed of Styragel packed columns HR1, HR3, HR4E, and HR5E (Waters Division Millipore). SEC was calibrated with poly(methyl methacrylate) (PMMA) standards (Polymer Laboratories, Ltd.) ranging between $2.4 \times 10^{6}$ and $9.7 \times 10^{2} \mathrm{~g} / \mathrm{mol}$. The Fourier Transform Infrared (FTIR) spectra of $\mathrm{KBr}$ pellets were recorded using a PerkinElmer Spectrum One.

Materials for biological experiments were already sterile or were sterilized in an autoclave before use. The optical density of the microorganism suspensions was measured in McFarland units by a DensiCHEKTM Plus (VITEK, bioMérieux) and incubations were performed at $37{ }^{\circ} \mathrm{C}$ in a Jouan IQ050 incubator. Absorbances of 96well plates were read with a Triturus microplate reader (Grifols).

Preparation of PBMA Macroinitiators. Poly(butyl methacrylate) macroinitiators were obtained by atom transfer radical polymerization (ATRP) in toluene at $100{ }^{\circ} \mathrm{C}$ and in the presence of $\mathrm{CuBr} / \mathrm{PMDETA}$ as catalyst using similar conditions as reported in the literature for methacrylate monomers. ${ }^{22-24}$ The purities of the resulting polymers, $\mathrm{PBMA}_{70}-\mathrm{Br}\left(M_{\mathrm{n}}=9900 \mathrm{~g} / \mathrm{mol} ; M_{\mathrm{w}} / M_{\mathrm{n}}=1.24\right)$ and $\mathrm{PBMA}_{132}-\mathrm{Br}\left(M_{\mathrm{n}}\right.$ $\left.=18770 \mathrm{~g} / \mathrm{mol}, M_{\mathrm{w}} / M_{\mathrm{n}}=1.18\right)$, were confirmed from ${ }^{1} \mathrm{H}$ NMR spectra and their molecular weights and polydispersity indexes determined by SEC, relative to PMMA standards.

Preparation of Block Copolymers Having Statistical Hydrophilic Copolymer Segment: PBMA -b-P(DMAEMA-co-HEMAGI). 


\section{Scheme 1. Schematic Representation of the Diverse Copolymers' Synthesis}

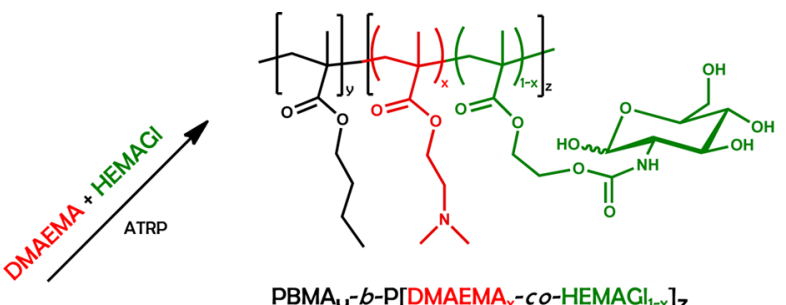

PBMA $_{y}-b-$ P[DMAEMA $x$-co-HEMAGi $\left.{ }_{1-x}\right]_{z}$
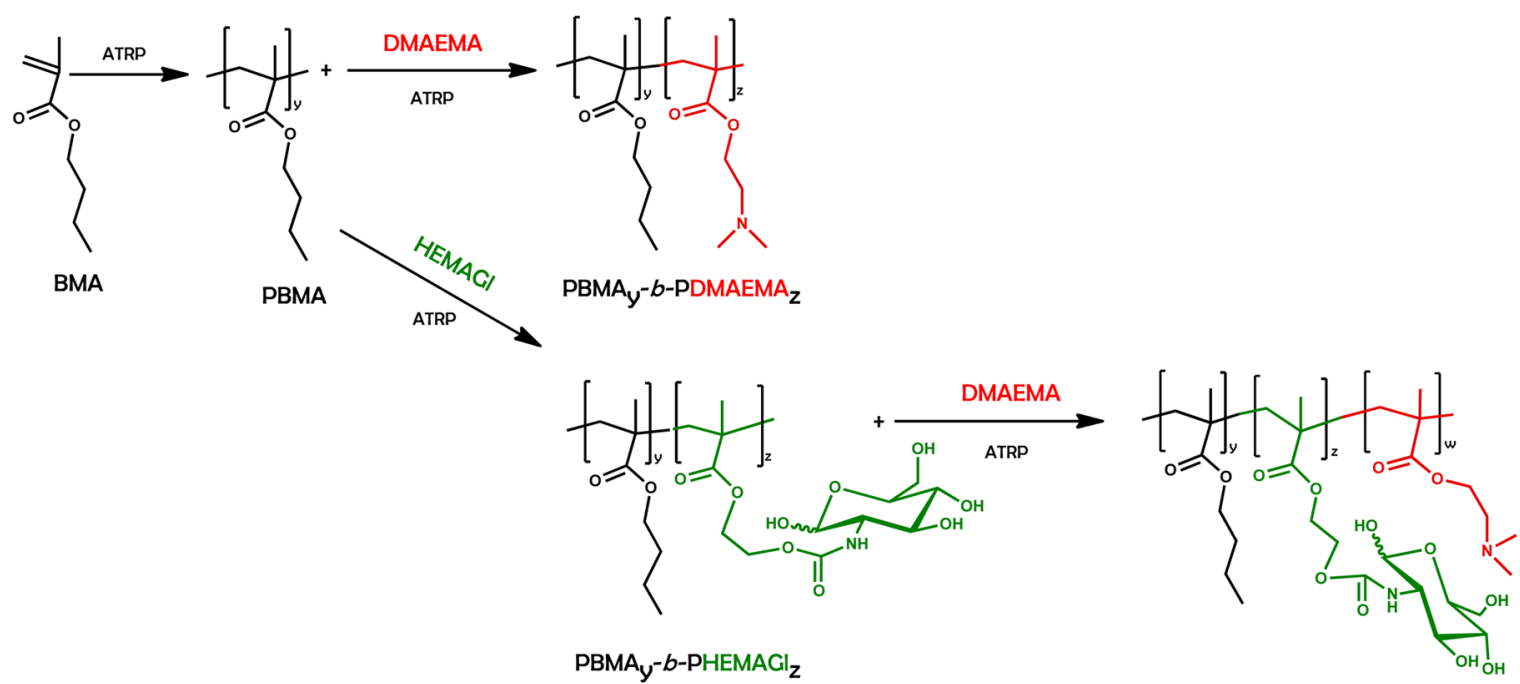

PBMA $_{y}-b-$ PHEMAGI $_{z}-b-$ PDMAEMA $_{w}$

Statistical copolymerizations of DMAEMA and 2-\{[(D-glucosamin-2$\mathrm{N}$-yl)carbonylethyl methacrylate (HEMAGl, synthesized following a procedure described previously by our group ${ }^{25}$ ) monomers were carried out by ATRP copolymerization in a Schlenk tube from both PBMA-Br macroinitiators. $\mathrm{CuCl} / \mathrm{PMDETA}$ was used as catalyst in DMF at $80 \% \mathrm{w} / \mathrm{w}$ ( $80 \%$ of total weight is the solvent). Initial DMAEMA mole fractions in the monomer feed for the second block were $0.25,0.5$, and 0.75 . The solution was purged with argon during at least 20 min before adding $\mathrm{CuCl}$ and PMDETA sequentially. The tube was immediately submerged in a thermostated bath at $90{ }^{\circ} \mathrm{C}$ for $4 \mathrm{~h}$, after which the reaction was stopped by cooling (up to $20{ }^{\circ} \mathrm{C}$ ), exposing catalyst to air and diluting with DMF. The final products were isolated by dialysis against distilled water for $72 \mathrm{~h}$ and lyophilized. Final compositions of block copolymers were determined via ${ }^{1} \mathrm{H}$ NMR spectroscopy.

In addition to the PBMA- $b$-P(DMAEMA-co-HEMAGl) copolymers, PBMA- $b$-PDMAEMA, PBMA- $b$-PHEMAGl and PBMA- $b$-PHEMAGl$b$-PDMAEMA diblock and triblock copolymers were also synthesized from PBMA macroinitiators using the same procedure, as described above. PDMAEMA homopolymer $\left(M_{\mathrm{n}}=12100 \mathrm{~g} / \mathrm{mol} ; M_{\mathrm{w}} / M_{\mathrm{n}}=\right.$ 1.16) was also synthesized for comparative purposes as described in the literature. ${ }^{26}$ The compositions were determined by ${ }^{1} \mathrm{H}$ NMR.

Quaternization of Synthesized Polymers. All synthesized polymers containing DMAEMA were quaternized to quaternary amine trimethylaminoethyl methacrylate (DMAEMAQ). Polymers were dissolved in DMF and methylation reaction was carried out with two equivalents of methyl iodide per amine group at room temperature. Full quaternatization was achieved after $24 \mathrm{~h}$ of reaction as confirmed by FTIR and NMR spectroscopies of resultant polymers. Solvent and methyl iodide excess were eliminated by dialysis and lyophilization, after which a washing step with hexane was performed to ensure the complete elimination of methyl iodide.

Evaluation of Antimicrobial Activity. Antimicrobial activities of the synthesized polymers were evaluated by determining their minimum inhibitory concentrations (MIC) against the bacterial strains
$S$. aureus, $S$. epidermidis, and $P$. aeruginosa and the fungal strain $C$. parapsilosis. Starting from stock solutions containing $1 \mathrm{mg} / \mathrm{mL}$ of polymer the standard broth microdilution method ${ }^{27}$ was applied to obtain the MIC. The noncomplete solubility of polymers in aqueous media necessitated an additional first step in which the polymers are dissolved in DMSO. This solution was then diluted with sterile Mueller-Hinton broth to obtain a final concentration of $1 \mathrm{mg} / \mathrm{mL}$ (the maximum final DMSO content should be below 6\%). Bacterial and fungal strains were grown in $5 \%$ sheep blood Columbia agar plates, dispersed, and adjusted with saline solution to a turbidity equivalent of $0.5-1 \mathrm{McF}$ arland turbidity standard $\left(1-3 \times 10^{8} \mathrm{CFU} / \mathrm{mL}\right)$. A 1:100 dilution with broth provides the bacteria suspension working solution $\left(10^{6} \mathrm{CFU} / \mathrm{mL}\right)$. For the broth microdilution method, as a general procedure, $100 \mu \mathrm{L}$ from each polymer stock solution were placed in a 96-well round-bottom microplate. From these ones, $50 \mu \mathrm{L}$ were half diluted with $50 \mu \mathrm{L}$ broth and then, subsequent 1:2 serial dilutions were made across the plate. A well without antimicrobial agent, containing only bacteria or fungi, was used as positive growth control. After 24 or $48 \mathrm{~h}$ of incubation at $37{ }^{\circ} \mathrm{C}$ for bacteria and fungi, respectively, the MIC was visually determined from the lowest concentration of antimicrobial agent at which no bacterial growth was observed.

Hemolytic Activity $\left(\mathrm{HC}_{50}\right)$. The capability of the synthesized polymers to induce hemolysis of erythrocytes was studied on fresh human blood obtained from healthy donors. Whole blood was collected in blood collecting tubes containing EDTA as anticoagulant and centrifuged immediately after extraction at $3500 \mathrm{rpm}$ for $20 \mathrm{~min}$. Supernatant (plasma) was removed, buffy coat at the middle (containing white blood cells) was isolated and kept for a later white blood cells assay, while the red blood cells (RBC) at the bottom were subsequently washed with cool sterile PBS and centrifuged three times. Once the red blood cells were isolated, a $5 \% \mathrm{v} / \mathrm{v}$ suspension in PBS of red blood cells was prepared and used as working solution. Polymer stock solutions were prepared by dissolving the polymers first in DMSO and subsequent 2-fold dilution with PBS (20 or $40 \mathrm{mg}$ / $\mathrm{mL}$ ). For the hemolytic assay, $100 \mu \mathrm{L}$ from each polymer stock 
Table 1. Composition of Statistical Copolymers PBMA- $b$-P(DMAEMA-co-HEMAGl $)^{a}$

\begin{tabular}{|c|c|c|c|c|c|}
\hline macroinitiator & polymer & $f_{\text {DMAEMA }} / f_{\text {HEMAGl }}$ & $F_{\text {DMAEMA }} / F_{\text {HEMAGl }}$ & $F_{\mathrm{BMA}}$ & $M_{\mathrm{n}}(\mathrm{Da})$ \\
\hline \multirow[t]{3}{*}{$\mathrm{PBMA}_{70}$} & S1 PBMA $_{70}-b-\mathrm{P}\left(\mathrm{DMAEMA}_{0.18^{-}}-\mathrm{co}-\mathrm{HEMAGl}_{0.82}\right)_{89}$ & $0.25: 0.75$ & $0.18: 0.82$ & 0.44 & 27100 \\
\hline & S2 PBMA $_{70^{-}} b-\mathrm{P}\left(\mathrm{DMAEMA}_{0.53}-c o-\mathrm{HEMAGl}_{0.47}\right)_{234}$ & $0.50: 0.50$ & $0.53: 0.47$ & 0.23 & 56200 \\
\hline & S3 PBMA $_{70^{-}} b-\mathrm{P}\left(\mathrm{DMAEMA}_{0.68^{-}} \text {co-HEMAGl }{ }_{0.32}\right)_{263}$ & $0.75: 0.25$ & $0.68: 0.32$ & 0.21 & 56100 \\
\hline \multirow[t]{3}{*}{$\mathrm{PBMA}_{132}$} & S4 PBMA ${ }_{132^{-}} b$-P(DMAEMA ${ }_{0.38^{-}}$- $\left.o-\mathrm{HEMAGl}_{0.62}\right)_{117}$ & $0.25: 0.75$ & $0.38: 0.62$ & 0.53 & 31230 \\
\hline & S5 PBMA $_{132}-b$-P(DMAEMA $\left.{ }_{0.63}-c o-\mathrm{DEMAGl}_{0.37}\right)_{224}$ & $0.50: 0.50$ & $0.63: 0.37$ & 0.37 & 49830 \\
\hline & 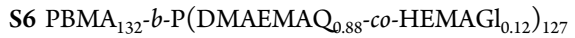 & $0.75: 0.25$ & 0.88:0.12 & 0.51 & 22630 \\
\hline
\end{tabular}

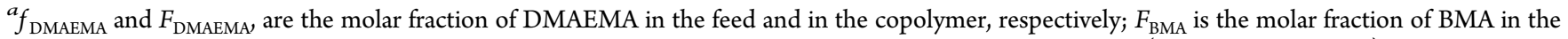
copolymer; and $M_{\mathrm{n}}$, is the number average molecular weight estimated by NMR of statistical copolymers (hydrophilic segment).

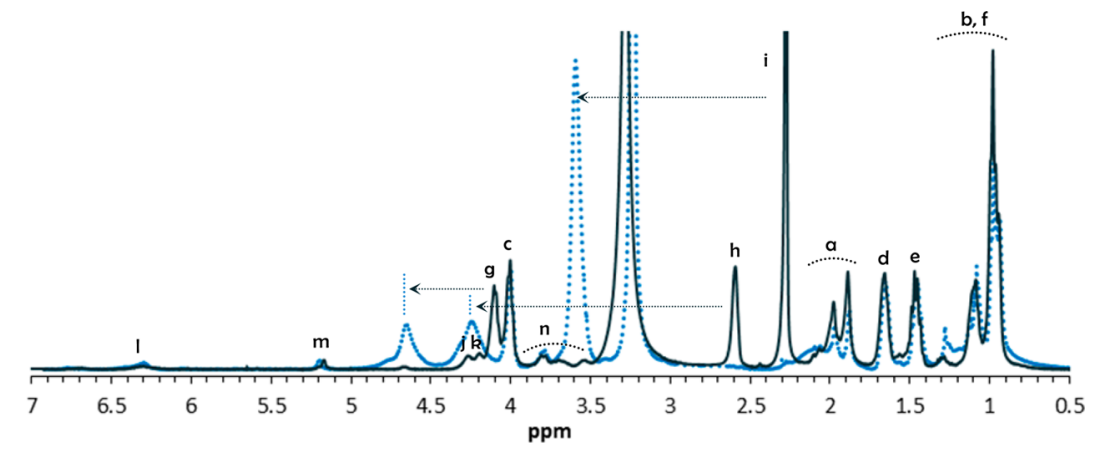

Figure 1. Scheme of $\mathrm{PBMA}_{y}-\mathrm{b}$-P(DMAEMA $\left.\mathrm{DM}_{x}-\mathrm{co}-\mathrm{HEMAGl}_{1-x}\right)_{z}$ block copolymer structure and ${ }^{1} \mathrm{H}$ NMR spectrum of copolymer S6 (solid line) and its quaternized derivative $S 6 \mathrm{Q}$ (dotted line).

solution were placed in a 96-well round-bottom microplate and 2-fold serial dilutions were performed with PBS. ${ }^{16,19,28}$ Then, $150 \mu \mathrm{L}$ of $5 \%$ red blood cell suspension were added to each well. Triton X-114 (50 $\mu \mathrm{L}$ of a $1 \% \mathrm{v} / \mathrm{v}$ solution in PBS) was used as positive control for $100 \%$ of hemolysis. Also, a negative control consisting of $150 \mu \mathrm{L}$ of red blood cell suspension mixed with $50 \mu \mathrm{L}$ of PBS was placed in order to obtain $0 \%$ hemolysis data and correct absorbance values. The microplate was incubated for $1 \mathrm{~h}$ at $37{ }^{\circ} \mathrm{C}$, centrifuged at $1000 \mathrm{rpm}$ during $10 \mathrm{~min}$ and the supernatant was then transferred to an empty 96-well microplate to measure hemoglobin absorbance at $550 \mathrm{~nm}$ using a Triturus (Grifols) microplate reader. DMSO was demonstrated to be nontoxic at the experimental concentrations used in this study.

Cytotoxicity Assay with White Blood Cells. Cytotoxicity against white blood cells (WBC) was evaluated using the alamar blue assay. Through this colorimetric assay the reduction of white blood cells viability when exposed to antimicrobial polymers relative to untreated cells was determined. Once white blood cells were isolated from whole blood as described above it is necessary to clean them completely from red blood cells to avoid interactions with polymers and possible colorimetric interferences. Red blood cell traces were eliminated by lysis of erythrocytes with ammonium chloride lysing solution. ${ }^{29}$ This isolation method ensures a good viability of the cells after the treatment. Cleaned white blood cells were suspended in RPMI-1640 medium at the desired concentration. After optimization, an optimum cell concentration of $8.4 \times 10^{4}$ cells $/ \mathrm{mL}$ and incubation time of $20 \mathrm{~h}$ were chosen as experimental conditions to be used in the alamar blue assay. The number of white blood cells in the final suspension was assessed by trypan blue dye exclusion and subsequent counting in a Neubauer chamber. The polymer stock solutions were the same as those utilized for hemolytic assays.

In a same way, and following manufacturer instructions for executing alamar blue assays, polymer solutions $(50 \mu \mathrm{L})$ were placed in a 96-well round-bottom microplate, followed by 2 -fold serial dilutions with RPMI-1640 medium and addition of $100 \mu \mathrm{L}$ of white blood cells suspension to each well. After $1 \mathrm{~h}$ of incubation at $37^{\circ} \mathrm{C}$, $15 \mu \mathrm{L}$ of alamar blue were added to each well, and subsequently, the microplate was placed again into an incubator for $24 \mathrm{~h}$. Absorbances were measured at 550 and $620 \mathrm{~nm}$ (corresponding to the reduced and oxidized forms of alamar blue, respectively) in a microplate reader and cytotoxicity was determined by comparison against the positive growth control (only white blood cells in RPMI-1640 medium). Blanks of RPMI medium and colored polymers were measured before the alamar blue addition to correct the final absorbance values.

Reproducibility and Statistical Analysis of Results. All experiments were done in triplicate at the same moment of the study and, in addition, MIC determination was repeated twice on different days. The data are expressed as mean values of replicated measurements and error bars correspond to standard deviations of the results.

\section{RESULTS AND DISCUSSION}

Synthesis of Copolymers. New amphiphilic copolymers were synthesized by atom transfer radical polymerization (ATRP) (see Scheme 1). The hydrophobic PBMA as macroinitiator was obtained by polymerization of butyl methacrylate in toluene at $100{ }^{\circ} \mathrm{C}$ using 1 equiv of $\mathrm{CuBr}$ as catalyst, 1 equiv of PMDETA as ligand, and 1 equiv of ethyl 2bromoisobutyrate as initiator, $[\mathrm{BMA}] /[\mathrm{CuBr}] /[\mathrm{PMDETA}] /$ $[\mathrm{EBrIB}]=100$ or $200: 1: 1: 1 .^{30}$ Two macroinitiators with different lengths were obtained. Their characterization by ${ }^{1} \mathrm{H}$ NMR and SEC confirmed the structure and controllability of the reaction. The number-average molecular weights, $M_{n}$, were 9900 and $18770 \mathrm{~g} / \mathrm{mol}$ corresponding to polymerization degrees of 70 and 132 units, respectively, $\left(\mathrm{PBMA}_{70}\right.$ and $\mathrm{PBMA}_{132}$ ) and their polydispersity indexes were relatively low, 1.24 for $\mathrm{PBMA}_{70}$ and 1.18 for PBMA 132 . The obtained PBMAs were later used as macroinitiators to polymerize hydrophilic blocks composed of DMAEMA and HEMAGl in statistical distributions using a halogen exchange catalyst system, $\mathrm{CuCl} /$ PMDETA, for better reaction control. ${ }^{31}$ Molar ratios for catalyst, ligand and initiator were maintained at one equivalent while DMAEMA mole fractions were changed to obtain three different compositions: $0.25,0.5$, and 0.75 ; the relationship is $[$ DMEMA + HEMAGl $] /[\mathrm{CuCl}] /[$ PMDETA $] /[$ EBrIB $]=100$ or 200:1:1:1. Additionally, diblock and triblock copolymers of DMAEMA and HEMAGl were prepared by ATRP using the same conditions as for the statistical copolymers. In the case of 
triblock copolymers, these were obtained polymerizing first the HEMAGl block and then the DMAEMA block to obtain PBMA- $b$-PHEMAGl- $b$-PDMAEMA. These copolymers could not be analyzed by SEC due to the excessive adhesion of DMAEMA in the separation columns. Final compositions of copolymers were then calculated from ${ }^{1} \mathrm{H}$ NMR spectra in DMF- $d_{7}$ at $70{ }^{\circ} \mathrm{C}$; these results are summarized in Table 1 . The $M_{\mathrm{n}}$ of the hydrophilic segment was then obtained from the composition, which is determined by NMR, subtracting the molecular weight of macroinitiator previously determined by SEC.

A typical ${ }^{1} \mathrm{H}$ NMR spectrum and the general chemical structure of the synthesized copolymers are shown in Figure 1. The quadruplet (e) at about $1.5 \mathrm{ppm}$ corresponding to $\mathrm{CH}_{2} \mathrm{CH}_{3}$ of the BMA unit, the peak at $2.6 \mathrm{ppm}$ from the methylene protons adjacent to the amine group of DMAEMA, and the peak at $5.2 \mathrm{ppm}$ from the anomeric proton of HEMAGl were used as reference signals for calculating the copolymer composition. It is well-known that quaternary amines show better antimicrobial activities than tertiary, secondary, and primary ones. ${ }^{5,32}$ For this reason, DMAEMA was quaternized to its quaternary ammonium salt DMAEMAQ by reaction with an excess of methyl iodide at room temperature. ${ }^{33}$ Complete methylation was reached after $24 \mathrm{~h}$, as revealed by the shift of peaks at 2.3, 2.6, and $4.1 \mathrm{ppm}$ to $3.6,4.2$, and $4.7 \mathrm{ppm}$, respectively; all of these are associated with the nearest protons to the nitrogen of DMAEMA (see Figure 1). Quantitative quaternization was also confirmed by FTIR spectroscopy (see Supporting Information, Figure S1) with the disappearance of the 2760 and $2820 \mathrm{~cm}^{-1}$ bands attributed to the stretching vibration of carbon-hydrogen bonds in amines.

Similarly, the characterization of the di- and triblock copolymers was performed by NMR and the results are summarized in Table 2. Subsequently, the quaternization was performed for selected polymers and in all the cases the reaction was quantitative.

Table 2. Composition of Block Copolymers ${ }^{a}$

\begin{tabular}{|c|c|c|c|c|c|}
\hline \multicolumn{2}{|c|}{ polymer } & \multirow{2}{*}{$\frac{F_{\mathrm{BMA}}}{0.00}$} & \multirow{2}{*}{$\frac{F_{\text {DMAEMA }}}{1.00}$} & \multirow{2}{*}{$\frac{F_{\text {HEMAGl }}}{0.00}$} & \multirow{2}{*}{$\frac{M_{\mathrm{n}}(\mathrm{Da})}{12100}$} \\
\hline homopolymer & PDMAEMA & & & & \\
\hline $\begin{array}{l}\text { diblock } \\
\text { copolymer }\end{array}$ & $\begin{array}{l}\text { BD } \text { PBMA }_{70}-b- \\
\text { PDMAEMA }_{65}\end{array}$ & 0.52 & 0.48 & 0.00 & 10300 \\
\hline & $\begin{array}{c}\text { BH PBMA } \\
\text { PDMAEMA }_{440}-b\end{array}$ & 0.23 & 0.00 & 0.77 & 147430 \\
\hline \multirow[t]{2}{*}{$\begin{array}{l}\text { triblock } \\
\text { copolymer }\end{array}$} & $\begin{array}{l}\text { T1 } \text { PBMA }_{70}-b- \\
\text { PHEMAGl }_{6}-b- \\
\text { PDMAEMA }_{45}\end{array}$ & 0.58 & 0.37 & 0.05 & 9100 \\
\hline & $\begin{array}{l}\text { T2 } \text { PBMA }_{132}-b- \\
\text { PHEMAGl }_{25}-b- \\
\text { PDMAEMA }_{73}\end{array}$ & 0.57 & 0.32 & 0.11 & 19830 \\
\hline
\end{tabular}

${ }^{a} F_{\text {BMA }}, F_{\text {DMAEMA }}$ and $F_{\text {HEMAGl }}$ are the molar fractions of BMA, DMAEMA, and HEMAGl in the block copolymer, respectively, and $M_{\mathrm{n}}$ is the number average molecular weight estimated by NMR (hydrophilic segment).

Antimicrobial Studies. There are different parameters that influence the antimicrobial activity of polymers. It does not only depend on the antimicrobial moiety employed, but also on the physicochemical characteristics of the macromolecule as a whole, including the hydrophilic/hydrophobic balance, charge density, monomer nature, and its distribution within the polymer backbone among other things. ${ }^{6}$ For this reason, results can vary from those expected based on the literature for similar polymers. To carry out a complete evaluation of the antimicrobial capability of these positively charged statistical, diblock and triblock copolymers, minimum inhibitory concentrations (MICs) against Gram-positive bacteria (S. aureus and S. epidermidis), Gram-negative bacteria ( $P$. aeruginosa), and fungi (C. parapsilosis) were determined by applying the broth microdilution method. ${ }^{21}$ In addition, quaternized PDMAEMA homopolymer and some of nonquaternized polymers were studied to compare the results. Polymer stock solutions were prepared at a concentration of $1 \mathrm{mg} / \mathrm{mL}$ in Mueller-Hinton broth with DMSO content up to 6\% (higher DMSO concentrations were demonstrated to be toxic for bacteria). ${ }^{34}$ For all the studied microbes, $100 \mu \mathrm{L}$ of each stock solution were placed in the first column of a 96-well plate and several half-dilutions were done across the plate maintaining the last column as positive growing control. Then, $50 \mu \mathrm{L}$ of corresponding $10^{6} \mathrm{CFU} / \mathrm{mL}$ bacteria solution were added on each well and plates were incubated. By doing this, polymer concentrations tested varied from 500 to $0.5 \mu \mathrm{g} / \mathrm{mL}$. The measurements were done at least in triplicate and the results summarized in Table 3. As can be seen, the polymers behave differently depending on the microorganism strain, being more effective, with low MIC values, against Gram-positive $S$. epidermidis and $S$. aureus bacteria and against $C$. parapsilosis fungus and almost ineffective against Gram-negative $P$. aeruginosa and E. coli bacteria (E. coli data not shown). The double cellular membrane of Gram-negative bacteria complicates polymer permeation inside the bacteria, the inner membrane disruption, and finally, the bacterial death. ${ }^{35}$ It is important to remark that the quaternized polymers show smaller MIC values than their corresponding pristine ones. The best results obtained for statistical copolymers were for S6Q with a MIC equal to $8 \mu \mathrm{g} / \mathrm{mL}$ against $S$. epidermidis, while for block copolymers the lowest MIC value was found for BDQ (4 $\mu \mathrm{g} / \mathrm{mL})$.

As mentioned above, PDMAEMAQ homopolymer was studied because it is considered to be an excellent antimicrobial polymer but at the same time, depending on the cell types and the concentration used, can be cytotoxic. ${ }^{36-38}$ It is clear that copolymers with low or no DMAEMA content such as S1Q and $\mathrm{BH}$ do not show any antimicrobial activity. In contrast, almost similar antimicrobial abilities are found in the cases of S6Q, BDQ and T1Q polymers, which contain the highest mole fractions of quaternized DMAEMA, confirming that the DMAEMA content is crucial for the antimicrobial activity (Figure 2a). A minimum DMAEMA content, $F_{\text {DMAEMA }}>0.3$, is needed to achieve comparable values to BDQ or PDMAEMAQ. It has been demonstrated that polymers with DMAEMA contents lower than 0.1 are not able to kill bacteria or fungi. ${ }^{16}$

Considering the hydrophobic BMA block in the copolymer, it can be seen in Figure 2 that an increase in the global composition of BMA produces a reduction in MIC values to reach a minimum at intermediate composition, $F_{\mathrm{BMA}} \sim 0.5$. Higher BMA contents will result in higher hydrophobicity and then, an imbalance between hydrophobic and hydrophilic segments. The later could produce an increase of the MIC values ${ }^{17}$ besides favoring the polymer insolubility.

Hemolytic Assays. Absorbance measurements of released hemoglobin due to erythrocytes hemolysis produced by action of the copolymers against red blood cells were used to evaluate their toxicity. The positive control to produce $100 \%$ of hemolysis (maximum absorbance) was $1 \%$ Triton X-114 in PBS, which acts as a detergent for cell membranes disrupting 
Table 3. Minimum Inhibitory Concentrations $(\mu \mathrm{g} / \mathrm{mL})$ Obtained for Quaternized $(\mathrm{Q})$ and Some Native Polymers against Bacteria and Fungi Strains ${ }^{a}$

\begin{tabular}{|c|c|c|c|c|c|c|c|}
\hline & $F_{\text {BMA }}$ & $F_{\text {DMAEMA }}$ & $F_{\text {HEMAGl }}$ & S. aureus & S. epidermidis & P. aeruginosa & C. parapsilosis \\
\hline S1Q & 0.44 & 0.10 & 0.46 & $>500$ & $>500$ & $>500$ & $>500$ \\
\hline S2 & 0.23 & 0.41 & 0.36 & $>500$ & 125 & & \\
\hline S2Q & & & & 125 & 32 & $>500$ & 32 \\
\hline S3Q & 0.21 & 0.54 & 0.25 & 32 & 8 & 500 & 32 \\
\hline$S 4 Q$ & 0.53 & 0.18 & 0.29 & 125 & 62 & $>500$ & $>500$ \\
\hline S5 & 0.37 & 0.40 & 0.23 & 125 & 62 & & \\
\hline S5Q & & & & 125 & 32 & 500 & $>500$ \\
\hline S6 & 0.51 & 0.43 & 0.06 & 32 & 16 & & \\
\hline S6Q & & & & 16 & 8 & 250 & 8 \\
\hline PDMAEMAQ & 0.00 & 1.00 & 0.00 & 16 & 4 & 250 & 16 \\
\hline BDQ & 0.52 & 0.48 & 0.00 & 32 & 4 & $>500$ & 8 \\
\hline $\mathrm{BH}$ & 0.23 & 0.00 & 0.77 & $>500$ & $>500$ & $>500$ & $>500$ \\
\hline T1Q & 0.58 & 0.37 & 0.05 & 16 & 16 & 250 & 8 \\
\hline $\mathrm{T} 2 \mathrm{Q}$ & 0.57 & 0.32 & 0.11 & 64 & 32 & 250 & 16 \\
\hline
\end{tabular}

${ }^{a} F_{\text {BMA }}, F_{\text {DMAEMA }}$ and $F_{\text {HEMAGl }}$ are the molar fractions in the copolymer of BMA, DMAEMA, and HEMAGl, respectively.
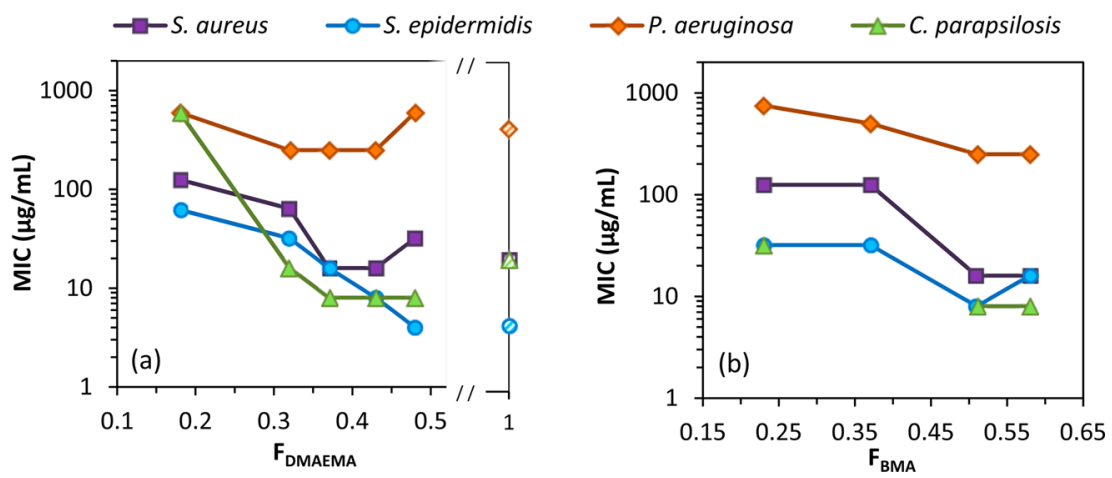

Figure 2. MIC dependence on BMA and DMAEMA content in the copolymers. (a) Polymers S4Q S6Q, T1Q, and T2Q with similar BMA content and values for PDMAEMAQ homopolymer (streaked fill) and (b) polymers S2Q, S5Q, S6Q and T1Q with similar DMAEMA content.
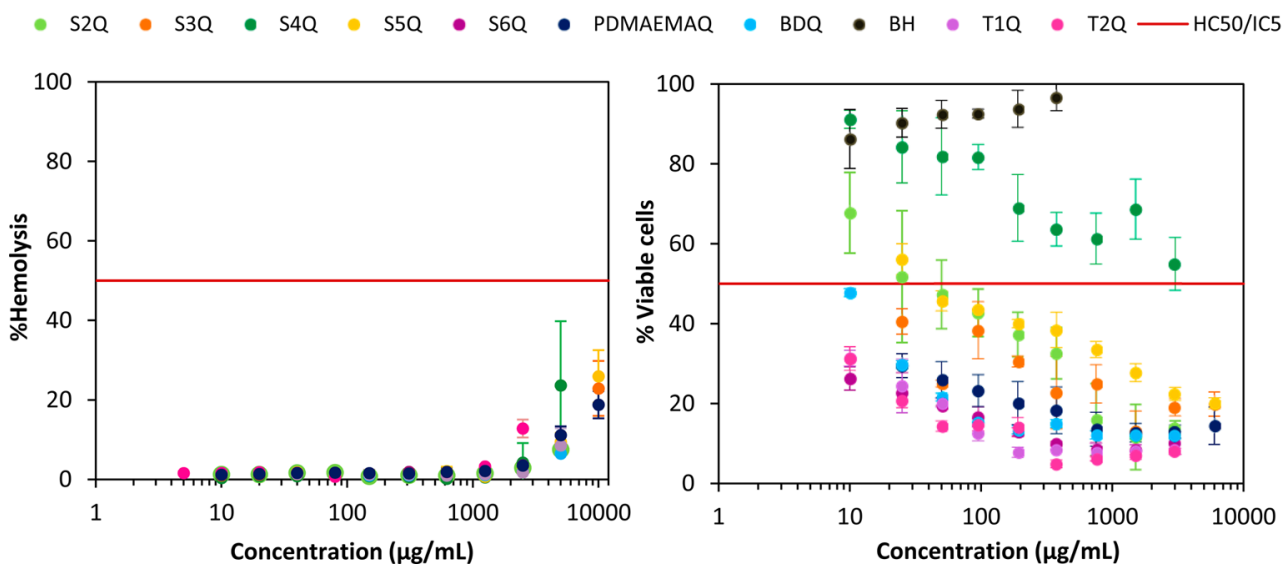

Figure 3. Toxicity of quaternized polymers for red blood cells represented as percentage of hemolyzed erythrocytes (left) and as percentage of viable white blood cells (right) against concentration. Red line situated at $50 \%$ represents theoretical $\mathrm{HC}_{50}$ and $\mathrm{IC}_{50}$ (half maximal inhibitory concentration) for red and white blood cells, respectively. ${ }^{39}$

them completely. The recorded absorbance for each polymer relative to the absorbance corresponding to $100 \%$ hemolysis determines the polymer toxicity (see Supporting Information for data analysis details). Hemolysis produced by quaternized polymers was studied at concentrations limited by the solubility of the polymers. The concentration used was $5 \mathrm{mg} / \mathrm{mL}$ for all of copolymers except for T2Q $(2.5 \mathrm{mg} / \mathrm{mL}), \mathrm{S} 3 \mathrm{Q}, \mathrm{S} 5 \mathrm{Q}$ and PDMAEMAQ $(10 \mathrm{mg} / \mathrm{mL})$.
Hemolytic activity is generally defined by the $\mathrm{HC}_{50}$ parameter, which represents the concentration of the toxic agent at which $50 \%$ of red blood cells are hemolyzed. In Figure 3 (left) is represented \%hemolysis against polymer concentration. The toxicity of S1Q was not determined because of its inactivity against any of the microbes studied, and although $\mathrm{BH}$ is inactive, its toxicity was estimated in this case to prove that the DMAEMA content is responsible for the polymer toxicity. 
Table 4. $\mathrm{HC}_{50}$ and $\mathrm{IC}_{50}$ and Their Selectivity Index Values of Quaternized Copolymers against S. aureus, S. epidermidis, P. aeruginosa, and C. parapsilosis

\begin{tabular}{|c|c|c|c|c|c|c|c|c|c|c|}
\hline & \multirow[b]{2}{*}{$\mathrm{HC}_{50}$} & \multirow[b]{2}{*}{$\mathrm{IC}_{50}$} & \multicolumn{2}{|c|}{ S. aureus } & \multicolumn{2}{|c|}{ S. epidermidis } & \multicolumn{2}{|c|}{ P. aeruginosa } & \multicolumn{2}{|c|}{ C. parapsilosis } \\
\hline & & & $\mathrm{SI}_{\mathrm{RBC}}$ & $\mathrm{SI}_{\text {WBC }}$ & $\mathrm{SI}_{\mathrm{RBC}}$ & SI $_{\text {WBC }}$ & $\mathrm{SI}_{\mathrm{RBC}}$ & $\mathrm{SI}_{\mathrm{WBC}}$ & $\mathrm{SI}_{\mathrm{RBC}}$ & $\mathrm{SI}_{\text {wBC }}$ \\
\hline S1Q & $\mathrm{n} / \mathrm{a}$ & $\mathrm{n} / \mathrm{a}$ & & & & & & & & \\
\hline S2Q & $>5000$ & 37 & $>40$ & 0.3 & $>150$ & 1.2 & & & $>150$ & 1.2 \\
\hline$S 3 Q$ & $>10000$ & $<25$ & $>300$ & $<0.8$ & $>1250$ & $<3$ & $>20$ & $<0.1$ & $>300$ & $<0.8$ \\
\hline S4Q & $>5000$ & $>3000$ & $>40$ & $>24$ & $>75$ & $>45$ & & & & \\
\hline S5Q & $>10000$ & 33 & $>80$ & 0.3 & $>300$ & 1 & $>20$ & 0.1 & & \\
\hline S6Q & $>5000$ & $<10$ & $>300$ & $<0.6$ & $>625$ & $<1.2$ & $>20$ & $<0.04$ & $>625$ & $<1.2$ \\
\hline PTMAEMAQ & $>10000$ & $<25$ & $>625$ & $<1.6$ & $>2500$ & $<2.5$ & $>40$ & $<0.1$ & $>625$ & $<1.6$ \\
\hline BDQ & $>5000$ & 10 & $>150$ & 0.3 & $>1250$ & 2.5 & & $<0.02$ & $>625$ & 1.2 \\
\hline $\mathrm{BH}$ & $>5000$ & $>3000$ & & & & & & & & \\
\hline $\mathrm{T} 1 \mathrm{Q}$ & $>5000$ & $<10$ & $>300$ & $<0.6$ & $>300$ & $<0.6$ & $>20$ & $<0.04$ & $>625$ & $<1.2$ \\
\hline T2Q & $>2500$ & $<10$ & $>40$ & $<0.2$ & $>75$ & $<0.3$ & $>10$ & $<0.04$ & $>150$ & $<0.6$ \\
\hline
\end{tabular}

As can be seen, the maximum \%hemolysis reached is under $30 \%$ in all the cases and no significant differences can be found between the different polymers. In fact, up to $1 \mathrm{mg} / \mathrm{mL}$ (which is twice the value of the highest MIC found) the survival of red blood cells was above of $95 \%$. This fact confirms that these polymers are not toxic for human erythrocytes. Moreover, the selectivity index (SI), which is defined as $\mathrm{HC}_{50} / \mathrm{MIC}$, is very satisfactory in all the cases (see Table 4). These values indicate that polymers are potentially clinically effective antimicrobial agents exhibiting selective toxicity toward the microorganism rather than the host.

White Blood Cell Viability. As mentioned above, the main goal of this study is to maintain the antimicrobial activity of PDMAEMA while decreasing its cytotoxicity. Incorporation of HEMAGl units into the copolymers should help to achieve the objective, higher activity with lower toxicity. Since white blood cells are essential in fighting infections and are more sensitive than red blood cells, we also studied the toxicity against these cells. It is worth mentioning that only a few studies have been published to date that investigate toxicities against white blood cells. Most related studies have been done with leukemic cells using a MTT assay test for cell viability. ${ }^{40-42}$ To the best of our knowledge, only a few studies used the alamar blue assay to measure the viability of entire peripheral white blood cells. ${ }^{4-45}$ This colorimetric assay determines cell viability under action of a toxic agent compared to untreated cells based on monitoring the redox process produced for cell metabolism on this reagent by measuring the absorbance at determined wavelengths with time. At the beginning, alamar blue is in its $100 \%$ oxidized form (blue and nonfluorescent) and during the experiment, the cell growth transforms it into its reduced form (red and fluorescent). The redox process can be monitored following the changes in absorbance or fluorescence values. A reduced medium is indicative of cell proliferation while an oxidized medium means growth inhibition. In this way, cell viability can be directly related to toxicity. Absorbances at 550 and $620 \mathrm{~nm}$ were monitored for this assay. Cell viability is obtained by comparing the reduction of alamar blue by the sample in the presence of toxic agents (polymers) with respect to the reduction produced by only white blood cells (see Supporting Information). First, cell number and time of reduction were optimized. A linear response between $1.6 \times 10^{4}$ and $2.6 \times 10^{5}$ cells per well in $24 \mathrm{~h}$ yields the working range (see Figure S2). The alamar blue assay was performed at $8.4 \times 10^{4} \mathrm{WBC} /$ well, and the results were determined at $20 \mathrm{~h}$. The test was carried out at a final polymer concentration of $6 \mathrm{mg} / \mathrm{mL}$ for S3Q S5Q and PDMAEMAQ and $3 \mathrm{mg} / \mathrm{mL}$ for all the others (first well discarded due to DMSO toxicity). Figure 3 (right) displays the viability of white blood cells at different polymer concentrations. It is clear that most of the polymers are highly toxic for white blood cells even at low concentrations. However, polymers with a considerable proportion of HEMAGl and low DMAEMA content, that is, $\mathrm{S} 4 \mathrm{Q}$ and $\mathrm{BH}$, are innocuous in the entire concentration range studied although they are very ineffective against microbes. Of particular interest are the S2Q and S5Q copolymers, which have similar DMAEMA content, approximately 0.40 , but HEMAGl molar fractions in the copolymer of 0.36 and 0.23 , respectively. These polymers have $\mathrm{IC}_{50}$ values of 37 and $33 \mu \mathrm{g} / \mathrm{mL}$, respectively; indicating that they are not toxic at these concentrations. The two most toxic polymers are S6Q and T1Q with only 0.05 and 0.11 mole fractions of HEMAGl, respectively. From these results it may be concluded that maintaining the DMAEMA content constant, a certain amount of HEMAGl in the copolymer can decrease the polymer toxicity. This is in line with what was previously found for cationic polymers in gene transfer applications: the incorporation of glycounits in the structure decreases their toxicity. ${ }^{20,46}$ Moreover, the copolymers with statistical hydrophilic block showed greater cell viability than the triblock copolymer containing comparable HEMAGl and DMAEMAQ content. To the best of our knowledge, this is the first study, which has evaluated the role of glycopolymers on antimicrobial cationic polymers.

\section{CONCLUSIONS}

In summary, novel amphiphilic block copolymers containing DMAEMA and HEMAGl units well-arranged in a statistical or block manner in the hydrophilic segment have been synthesized by atom transfer radical polymerization. It has been demonstrated the necessity to have a perfect balance between hydrophilicity and hydrophobicity or positive charge density, as well as a distribution of the active sites along the structure, to achieve a nontoxic and potent antimicrobial polymer. Remarkably, it was established that the incorporation of certain amount of carbohydrate pendants groups increases the cell viability while maintaining the antimicrobial activity. Therefore, the appropriate antimicrobial polymer will depend on the final application the polymer. For instance, S6Q (i.e., PBMA $_{132}-b$-P(DMAEMAQ $\left.\left.0.88^{-c o-H E M A G l}{ }_{0.12}\right)_{127}\right)$ and T1 (i.e., PBMA $_{132}-b$-PDMAEMAQ $45-b$-PHEMAGl 6 ) would be very promising materials against Gram-positive bacteria and fungi in coatings and paints because their demonstrated high 
antimicrobial activity, whereas S4Q (i.e., $\mathrm{PBMA}_{132}-b$-P-

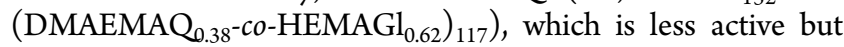
also less harmful, could potentially be used in vivo treatments. Obviously, it is always dangerous to extrapolate in vitro results to real clinical applications and further in vivo studies will be required.

\section{ASSOCIATED CONTENT}

\section{S Supporting Information}

FTIR spectra of PBMA macroinitiator as well as S5 and S5Q statistical block copolymers. The data analysis details corresponding to the hemotoxicity and alamar tests. This material is available free of charge via the Internet at http:// pubs.acs.org.

\section{AUTHOR INFORMATION}

\section{Corresponding Author}

*E-mail: martafg@ictp.csic.es.

\section{Notes}

The authors declare no competing financial interest.

\section{ACKNOWLEDGMENTS}

This work was financially supported by the MINECO (Projects MAT2010-17016 and MAT2013-47902-C2-1-R). M.Á.-P. and A.M.-B. also acknowledge MINECO financial support for their FPI Grant and Ramon y Cajal Contract, respectively.

\section{REFERENCES}

(1) WHO Antimicrobial Resistance: Global Report on Surveillance. http://www.who.int/drugresistance/documents/surveillancereport/ en/, 2014

(2) Furuya, E. Y.; Lowy, F. D. Antimicrobial-resistant bacteria in the community setting. Nat. Rev. Microbiol. 2006, 4 (1), 36-45.

(3) Tashiro, T. Antibacterial and Bacterium Adsorbing Macromolecules. Macromol. Mater. Eng. 2001, 286 (2), 63-87.

(4) Kenawy, E.-R.; Worley, S. D.; Broughton, R. The chemistry and applications of antimicrobial polymers: a state-of-the-art review. Biomacromolecules 2007, 8 (5), 1359-1384.

(5) Muñoz-Bonilla, A.; Fernández-García, M. Polymeric materials with antimicrobial activity. Prog. Polym. Sci. 2012, 37 (2), 281-339.

(6) Muñoz-Bonilla, A.; Cerrada, M. L.; Fernández-García, M. Polymeric Materials with Antimicrobial Activity: From Synthesis to Applications. The Royal Society of Chemistry: U.K., 2014.

(7) Kanazawa, A.; Ikeda, T.; Endo, T. Polymeric phosphonium salts as a novel class of cationic biocides. II. Effects of counter anion and molecular weight on antibacterial activity of polymeric phosphonium salts. J. Polym. Sci., Part A: Polym. Chem. 1993, 31 (6), 1441-1447.

(8) Engler, A. C.; Tan, J. P. K.; Ong, Z. Y.; Coady, D. J.; Ng, V. W. L.; Yang, Y. Y.; Hedrick, J. L. Antimicrobial polycarbonates: investigating the impact of balancing charge and hydrophobicity using a samecentered polymer approach. Biomacromolecules 2013, 14 (12), 43314339.

(9) Vigliotta, G.; Mella, M.; Rega, D.; Izzo, L. Modulating antimicrobial activity by synthesis: dendritic copolymers based on nonquaternized 2-(dimethylamino)ethyl methacrylate by $\mathrm{Cu}$-mediated ATRP. Biomacromolecules 2012, 13 (3), 833-841.

(10) Yagci, M. B.; Bolca, S.; Heuts, J. P. A.; Ming, W.; de With, G. Self-stratifying antimicrobial polyurethane coatings. Prog. Org. Coat. 2011, 72 (3), 305-314.

(11) Yagci, M. B.; Bolca, S.; Heuts, J. P. A.; Ming, W.; de With, G. Antimicrobial polyurethane coatings based on ionic liquid quaternary ammonium compounds. Prog. Org. Coat. 2011, 72 (3), 343-347.

(12) You, Y. Z.; Manickam, D. S.; Zhou, Q. H.; Oupicky, D. Reducible poly(2-dimethylaminoethyl methaerylate): Synthesis, cytotoxicity, and gene delivery activity. J. Controlled Release 2007, 122 (3), 217-225.
(13) Nouri, A.; Castro, R.; Kairys, V.; Santos, J.; Rodrigues, J.; Li, Y.; Tomás, H. Insight into the role of $N, N$-dimethylaminoethyl methacrylate (DMAEMA) conjugation onto poly(ethylenimine): cell viability and gene transfection studies. J. Mater. Sci.: Mater. Med. 2012, 23 (12), 2967-2980.

(14) Wang, F. P.; Zhang, J. Y.; Mu, H. P.; Li, W. X.; Yuan, T.; Du, X. $\mathrm{Z}$. Preparation and application in drug controlled delivery of $\mathrm{pH}$ sensitive P(CE-co-DMAEMA-co-MEG) hydrogel. J. Appl. Polym. Sci. 2014, $131(17), \mathrm{n} / \mathrm{a}-\mathrm{n} / \mathrm{a}$.

(15) Zhao, W.; Róg, T.; Gurtovenko, A. A.; Vattulainen, I.; Karttunen, M. Role of phosphatidylglycerols in the stability of bacterial membranes. Biochimie 2008, 90 (6), 930-938.

(16) Palermo, E. F.; Kuroda, K. Chemical structure of cationic groups in amphiphilic polymethacrylates modulates the antimicrobial and hemolytic activities. Biomacromolecules 2009, 10 (6), 1416-1428.

(17) Kuroda, K.; Caputo, G. A.; DeGrado, W. F. The role of hydrophobicity in the antimicrobial and hemolytic activities of polymethacrylate derivatives. Chem.-Eur. J. 2009, 15 (5), 11231133.

(18) Dutta, P.; Dey, J.; Shome, A.; Das, P. K. Nanostructure formation in aqueous solution of amphiphilic copolymers of 2- $(\mathrm{N}, \mathrm{N}$ dimethylaminoethyl)methacrylate and alkylacrylate: Characterization, antimicrobial activity, DNA binding, and cytotoxicity studies. Int. J. Pharm. 2011, 414 (1-2), 298-311.

(19) Locock, K. E. S.; Michl, T. D.; Valentin, J. D. P.; Vasilev, K.; Hayball, J. D.; Qu, Y.; Traven, A.; Griesser, H. J.; Meagher, L.; Haeussler, M. Guanylated polymethacrylates: a class of potent antimicrobial polymers with low hemolytic activity. Biomacromolecules 2013, 14 (11), 4021-4031.

(20) Ahmed, M.; Narain, R. The effect of polymer architecture, composition, and molecular weight on the properties of glycopolymerbased non-viral gene delivery systems. Biomaterials 2011, 32 (22), 5279-5290.

(21) CLSI, Methods for Dilution Antimicrobial Susceptibility Tests for Bacteria That Grow Aerobically; Approved Standard. CLSI Document M07-A9, 9th ed.; Clinical and Laboratory Standards Institute: Wayne, PA, 2012.

(22) de la Fuente, J. L.; Fernandez-Sanz, M.; Fernandez-Garcia, M.; Madruga, E. L. Solvent effects on the synthesis of poly(methyl methacrylate) by atom-transfer radical polymerization (ATRP). Macromol. Chem. Phys. 2001, 202 (12), 2565-2571.

(23) Fernández-García, M.; de la Fuente, J. L.; Fernández-Sanz, M.; Madruga, E. L. The importance of solvent polar character on the synthesis of PMMA- $b$-PBA block copolymers by atom transfer radical polymerization. Polymer 2001, 42 (23), 9405-9412.

(24) Nanda, A. K.; Matyjaszewski, K. Effect of $[$ PMDETA $] /[\mathrm{Cu}(\mathrm{I})]$ ratio, monomer, solvent, counterion, ligand, and alkyl bromide on the activation rate constants in atom transfer radical polymerization. Macromolecules 2003, 36 (5), 1487-1493.

(25) León, O.; Bordegé, V.; Muñoz-Bonilla, A.; Sánchez-Chaves, M.; Fernández-García, M. Well-controlled amphiphilic block glycopolymers and their molecular recognition with lectins. J. Polym. Sci., Part A: Polym. Chem. 2010, 48 (16), 3623-3631.

(26) Munoz-Bonilla, A.; Fernandez-Garcia, M.; Haddleton, D. M. Synthesis and aqueous solution properties of stimuli-responsive triblock copolymers. Soft Matter 2007, 3 (6), 725-731.

(27) Kantouch, A.; El-Sayed, A. A. Polyvinyl pyridine metal complex as permanent antimicrobial finishing for viscose fabric. Int. J. Biol. Macromol. 2008, 43 (5), 451-455.

(28) Wei, G.; Liu, X.; Yuan, L.; Ju, X.-J.; Chu, L.-Y.; Yang, L. Lipid composition influences the membrane-disrupting activity of antimicrobial methacrylate copolymers. J. Biomater. Sci., Polym. Ed. 2011, 22 (15), 2041-2061.

(29) McCoy, J. J. P., Handling, Storage, and Preparation of Human Blood Cells. Current Protocols in Cytometry; John Wiley \& Sons, Inc.: New York, 2001.

(30) Martin-Gomis, L.; Fernandez-Garcia, M.; de la Fuente, J. L.; Madruga, E. L.; Cerrada, M. L. Physical properties of PBMA-b-PBA-b- 
PBMA triblock copolymers synthesized by atom transfer radical polymerization. Macromol. Chem. Phys. 2003, 204 (16), 2007-2016.

(31) Matyjaszewski, K.; Shipp, D. A.; Wang, J.-L.; Grimaud, T.; Patten, T. E. Utilizing halide exchange to improve control of atom transfer radical polymerization. Macromolecules 1998, 31 (20), 68366840.

(32) Timofeeva, L.; Kleshcheva, N. Antimicrobial polymers: mechanism of action, factors of activity, and applications. Appl. Microbiol. Biotechnol. 2010, 1-18.

(33) Bütün, V.; Armes, S. P.; Billingham, N. C. Selective quaternization of 2-(dimethylamino)ethyl methacrylate residues in tertiary amine methacrylate diblock copolymers. Macromolecules 2001, 34 (5), 1148-1159.

(34) Hansen, L. K.; Brown, M.; Johnson, D.; Palme, D. F.; Love, C.; Darouiche, R. In vivo model of human pathogen infection and demonstration of efficacy by an antimicrobial pouch for pacing devices. Pace-Pacing Clin. Electrophysiol. 2009, 32 (7), 898-907.

(35) Silhavy, T. J.; Kahne, D.; Walker, S. The bacterial cell envelope. Cold Spring Harbor Perspect. Biol. 2010, 2 (5), a000414.

(36) Lu, G. Q.; Wu, D. C.; Fu, R. W. Studies on the synthesis and antibacterial activities of polymeric quaternary ammonium salts from dimethylaminoethyl methacrylate. React. Funct. Polym. 2007, 67 (4), 355-366.

(37) Rawlinson, L. A. B.; Ryan, S. M.; Mantovani, G.; Syrett, J. A.; Haddleton, D. M.; Brayden, D. J. Antibacterial effects of poly(2(dimethylamino ethyl)methacrylate) against selected gram-positive and gram-negative bacteria. Biomacromolecules 2010, 11 (2), 443-453.

(38) Rawlinson, L. A. B.; O’Brien, P. J.; Brayden, D. J. High content analysis of cytotoxic effects of pDMAEMA on human intestinal epithelial and monocyte cultures. J. Controlled Release 2010, 146 (1), 84-92.

(39) Shaarawy, H. H.; El-Rafie, S. M.; Abd El-Ghaffar, A. M.; ElRafie, M. H. Electrocatalytic oxidation of rice starch using mixed oxidant generated via titanium/rhodium thermally activated modified electrode: Part (I). Carbohydr. Polym. 2009, 75 (2), 208-213.

(40) Pieters, R.; Loonen, A.; Huismans, D.; Broekema, G.; Dirven, M.; Heyenbrok, M.; Hahlen, K.; Veerman, A. In vitro drug sensitivity of cells from children with leukemia using the MTT assay with improved culture conditions. Blood 1990, 76, 2327-2336.

(41) Marks, D. C.; Belov, L.; Davey, M. W.; Davey, R. A.; Kidman, A. D. The MTT cell viability assay for cytotoxicity testing in multidrugresistant human leukemic cells. Leukemia Res. 1992, 16 (12), 11651173.

(42) van de Loosdrecht, A. A.; Beelen, R. H. J.; Ossenkoppele, G. J.; Broekhoven, M. G.; Langenhuijsen, M. M. A. C. A tetrazolium-based colorimetric MTT assay to quantitate human monocyte mediated cytotoxicity against leukemic cells from cell lines and patients with acute myeloid leukemia. J. Immunol. Methods 1994, 174 (1-2), 311320.

(43) Ansar Ahmed, S.; Gogal, R. M., Jr; Walsh, J. E. A new rapid and simple non-radioactive assay to monitor and determine the proliferation of lymphocytes: an alternative to $[3 \mathrm{H}]$ thymidine incorporation assay. J. Immunol. Methods 1994, 170 (2), 211-224.

(44) De Fries, R.; Mitsuhashi, M. Quantification of mitogen induced human lymphocyte proliferation: Comparison of alamarbluetm assay to 3H-thymidine incorporation assay. J. Clin. Lab. Anal. 1995, 9 (2), $89-95$.

(45) Millen, S. H.; Bernstein, D. I.; Connelly, B.; Ward, J. I.; Chang, S.-J.; Weiss, A. A. Antibody-mediated neutralization of pertussis toxininduced mitogenicity of human peripheral blood mononuclear cells. Infect. Immun. 2004, 72 (1), 615-620.

(46) Ahmed, M.; Narain, R. The effect of molecular weight, compositions and lectin type on the properties of hyperbranched glycopolymers as non-viral gene delivery systems. Biomaterials 2012, 33 (15), 3990-4001. 